\title{
Primary Intraosseous Squamous Cell Carcinoma
}

\author{
Maryam Mardani*
}

Department of oral medicine, School of Dentistry, Shiraz University of medical sciences, Shiraz, Iran

*Corresponding author: Maryam Mardani, Assistant Prof, Department of oral medicine, School of Dentistry, Shiraz University of medical sciences, Shiraz, Iran, E-mail: mardanim@sums.ac.ir

\section{Introduction}

Primary intraosseous squamous cell carcinoma (PIOSCC) is a rare epithelial odontogenic carcinoma in the jaw .It develops from remnants of the odontogenic epithelium or from an odontogenic cyst or tumor. Sometimes, there are no visible clinical features and it may cause delay in an accurate diagnosis. We report two cases with diagnosis of primary intraosseous squamous cell carcinoma

\section{Case 1}

A 65-year-oldman was referredto Oral and Maxillofacial medicinedepartment of Dental School ofShiraz University of Medical Science with a complaint of swelling on the right side of the mandible. The medical and family history was unremarkable. On careful history evaluation, the patient proposed that he was treated for right posterior mandibular pus discharge by a dentist 3 months ago by tooth 45 and 46 extraction.

On intraoral examination, a tender, diffuse swelling $(4 \mathrm{~cm} \times 5 \mathrm{~cm})$ was presented involving the buccal and lingual aspects of the edentulous ridge of 45,46 region extending from mesial side of right mandibular first premolar to right mandibular second molar. Ulcer with fibrino leukocytic membrane was seen on the surface, partly was normal in color and partly was red,firm in consistency, 43 and 44 had $3^{\text {rd }}$ grade mobility, 47 and 48 had $2^{\text {nd }}$ grade mobility, with no associated sinus tract or discharge. The right submandibular lymph node was palpable.

\section{Investigations}

Based on axial and multiplanar images of cone beam CT (CBCT), loss of continuity of buccal and lingual cortical plates of involved right mandible were seen.Also remnant of bone trabeculawas observed. Hanging in air appearance was obvious for $44,47,48$. Loss of continuity of the mandibular canal cortex on the affected side was also evident.

Based on reconstructed panoramic image, there was a large destructive lesion with an ill defined border in right side of the mandible extending from mesial side of right mandibular canine to the retromolar region.
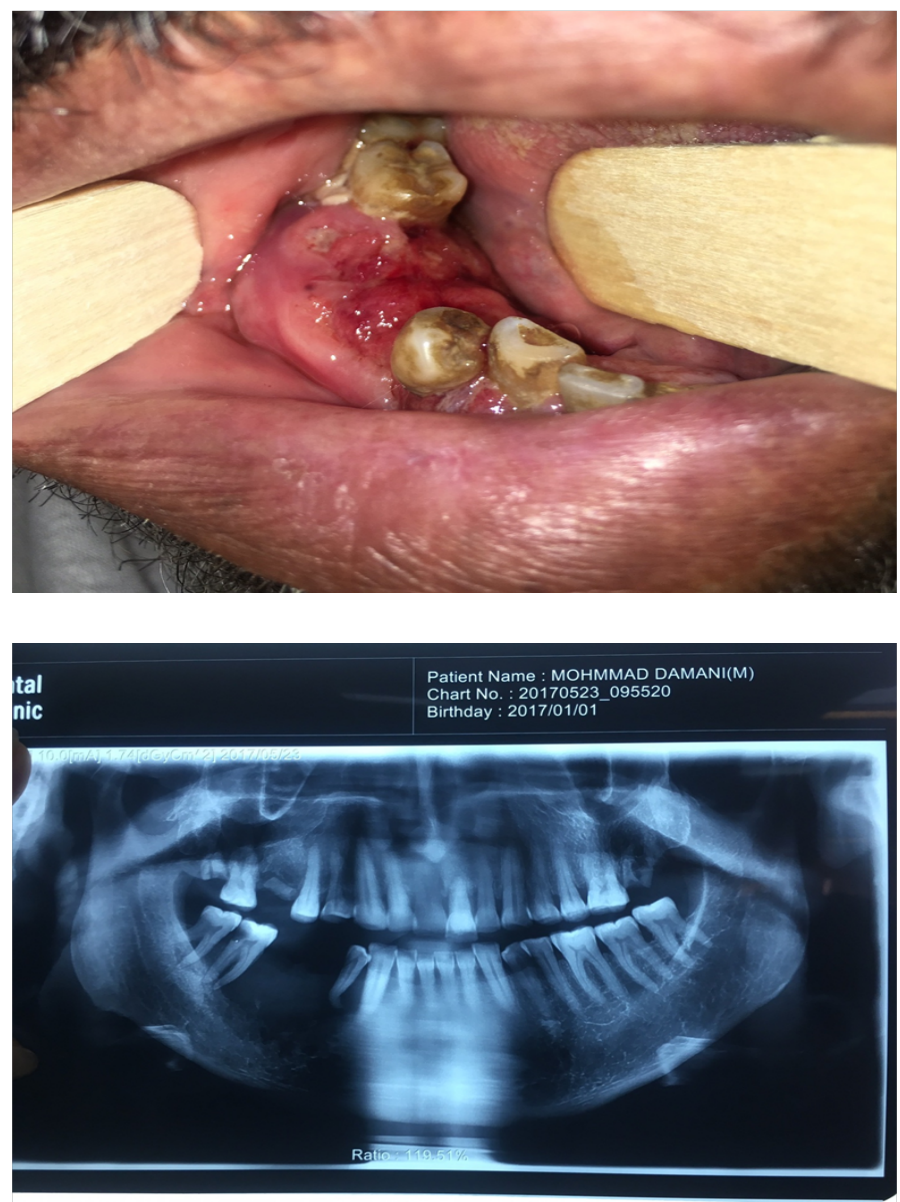

Received date: April 04, 2018

Accepted date: June 21, 2018

Published date: June 26, 2018

Citation: Mardani, M., et al. Primary Intraosseous Squamous Cell Carcinoma. (2018) J Dent Oral Care 4(1): 20- 22.

Copyright: (C) 2018 Mardani, M . This is an Open access article distributed under the terms of Creative Commons Attribution 4.0 International License. 

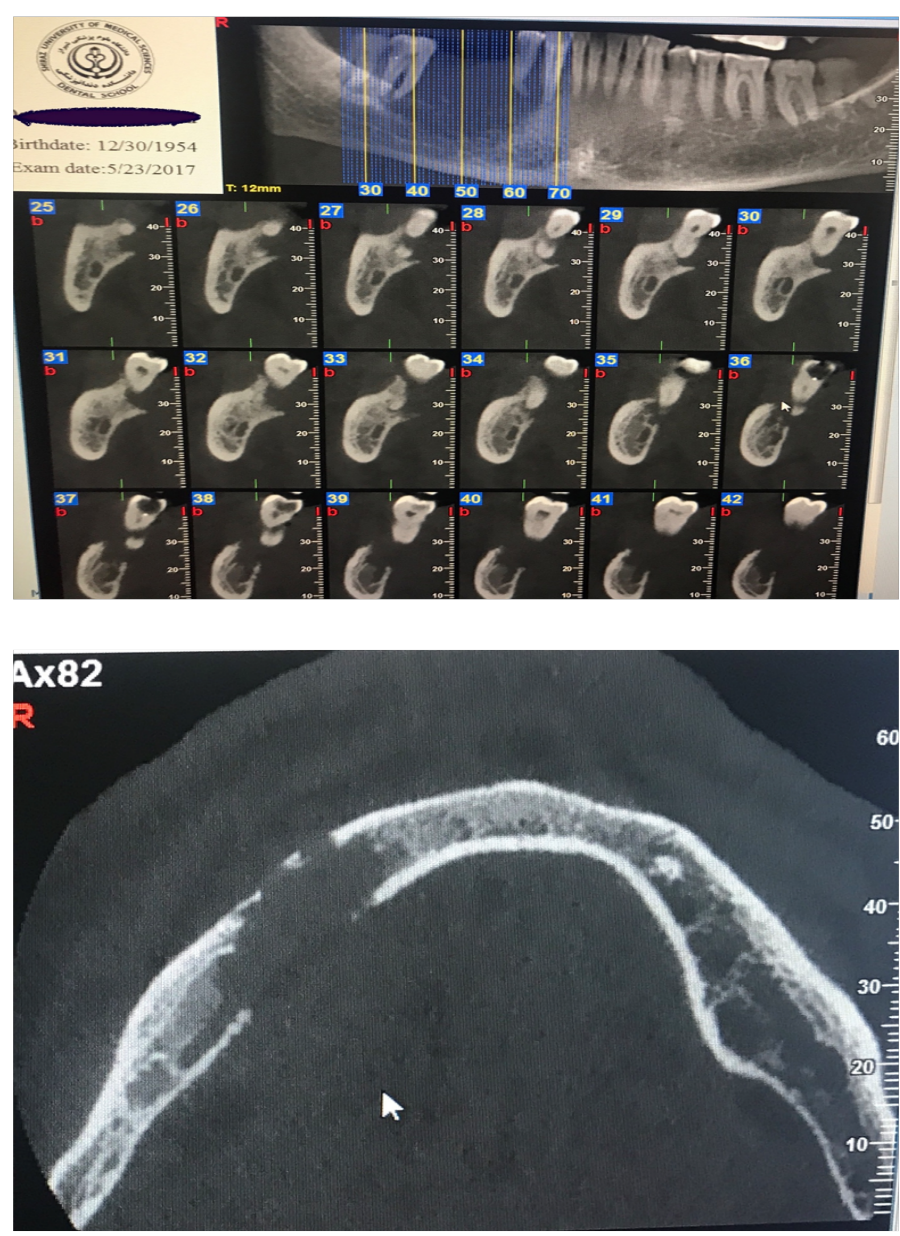

Case 2

A 46-year-old man referredto Oral and Maxillofacial Medicine Department of Shiraz University of Medical ScienceDental School with a complaint of ulcer on the right side of the mandible. The patient had a swelling onright mandibular region related to 47.Primary incisional biopsy was taken and its histopathologicfindings were not reliable. The medical and family history was unremarkable.

On intraoral examination there was an red lesion with an ulcer onits base, on right mandibular region extending from distal of 46 to mesial of $48(3 \mathrm{~cm} \times 2 \mathrm{~cm})$ with fibrino leukocytic membrane and no associated sinus or discharge. The right supraclavicular lymph node was palpable.

\section{Investigations}

On CBCT of the mandible,there was a lytic radiolucent lesion with poorly define borderon the right side of mandible associated with $1^{\text {st }}$ and $2^{\text {nd }}$ molars. The buccal cortical plate adjacent to the $1^{\text {st }}$ molar was eroded but the lingual cortical plate was intact. Also the crestal bone cannot be seen in the affected region. There was no evidence of root resorption or tooth displacement. Therewas no evidence of deep caries or severe periodontal disease; therefore the pulpoperiapical lesion was not palpable.

Based on reconstructed panoramic image, there was a large lyticradiolucency withill-defined and irregular border on right side of the mandible with periodontal ligament widening extending from distal side of right mandibular $1^{\text {st }}$ molar to the distal side of $2^{\text {nd }}$ mandibular right molar.
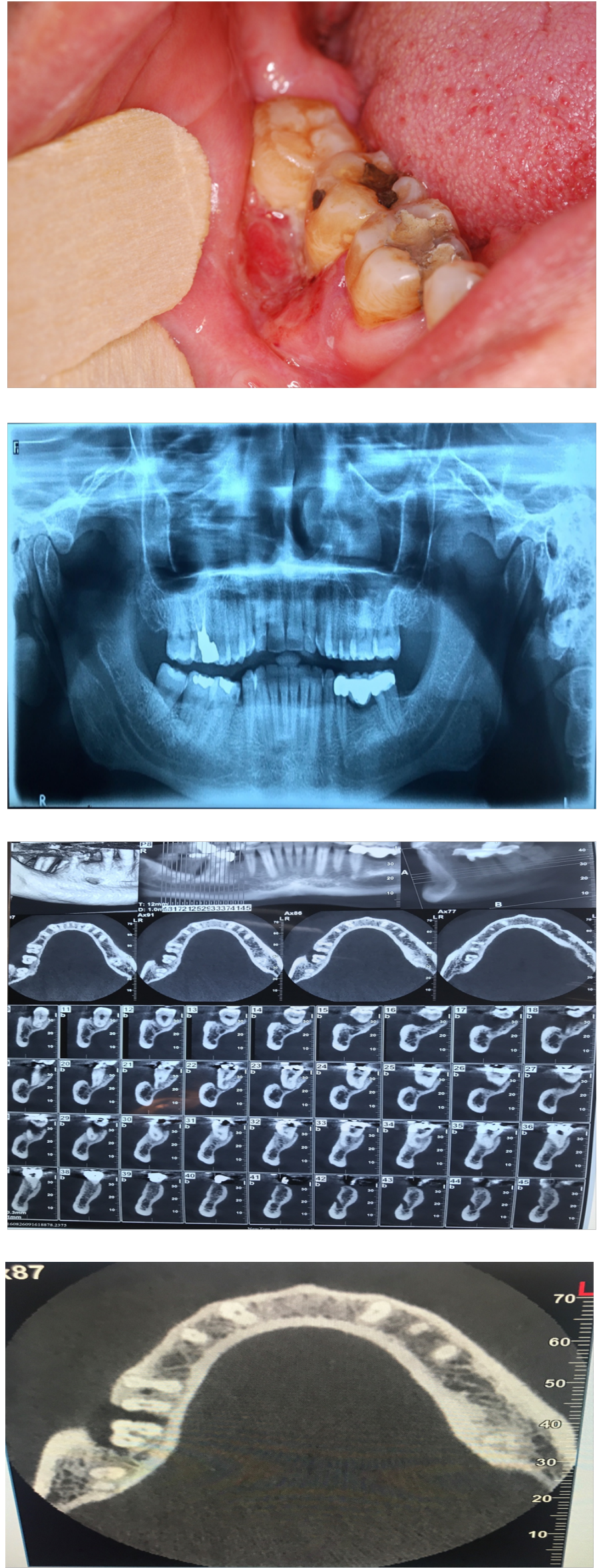


\begin{abstract}
Hostopathology
An incisional biopsy was performed under local anesthesia after explaining the procedure to the patient and obtaining the written consent. A histopathological examination showed dysplastic stratified squamous epithelium with dyskeratosis, severe exocytosis and papillary growth pattern. The underlying connective tissue demonstrates malignant epithelial tumor composed of nests and sheets of squamoid cells with pleomorphism, hyperchromatism and individual cell keratinization. Severe infiltrations of chronic inflammatory cells were also noticed. The histopathological feature was suggestive of a moderately differentiated squamous cell carcinoma (SCC)
\end{abstract}

\section{Treatment}

The patient underwent hemimandibulectomy with supra omohyoid neck dissection through a submandibular incision under general anaesthesia. The affected regional lymph nodes were dissected. All frozen sections from the surgical margin tissues were free of tumor. Subsequently, a reconstruction plate was used to reconstruct mandible. There was no evidence of recurrence till the patient last reported for a follow-up.

\section{Discussion}

PIOSCC/primary intraosseous odontogenic carcinoma (PIOC) is a SCC arising within the jawbones that has no original connection with the oral. Eversole et al., in 2005 used the term PIOSCC and further categorized into three subcategories of PIOSCCs, solid tumor that invades marrow spaces and induces osseous resorption, SCC arising from lining of an odontogenic cyst and SCC in association with other benign epithelial odontogenic tumors ${ }^{[1]}$.

PIOC affects men more with mean age of 57 years. It is more commonly located in posterior regions ofmandible. In maxilla, the anterior region is frequently involve and the lesion may cross the midline ${ }^{[2-5]}$.

Pain and swelling are the most common symptoms of patients with PIOC .It may remain clinically silent and in early phases found on routine dental radiographs. There is progressive swelling of jaws, loosening of teeth and paresthesia and numbness can occur due to compression of inferior alveolar nerve in advanced cases ${ }^{[5]}$ lymphadenopathy has been recorded with this tumor. Microscopically and histological features of PIOC and squamous cell carcinomaare the same.

Many studies show that, radiologically $61 \%$ of PIOC showed a unilocular radiolucency resembling a cyst which is varying in size, shape and margins. In most of casesmargins are irregular and ill defined. Since invasion probably occurs along the path of least resistance, this would not cause root resorption or displacement.

Malignant tumors of odontogenic epithelium, including ameloblastic carcinoma, intraosseous mucoepidermoid carcinoma, clear cell odontogenic carcinoma, odontogenic ghost cell carcinoma, and malignant variant of calcifying epithelial odontogenic tumor (CEOT) should be considered in differential diagnosis and squamous cell carcinoma of mucosal origin, ac- anthomatous ameloblastoma, squamous odontogenic tumor, and CEOT also should be ruled out ${ }^{[2]}$.

Treatment of choice is surgery. Enblock excision or radical resection of involved bone. Radiotherapy and chemotherapy may be used as adjunctive therapy ${ }^{[3-5]}$.

\section{Conclusion}

Our case highlights that diagnosis of PIOC is very difficult and radiographic examination is an effective methods to detect PIOC.Early diagnosis of PIOC can affect the prognosis, so a dentist should be concern and examine the lesion carefully.

\section{References}

1. Bodner L, Manor E, Shear M, et al. Primary intraosseous squamous cell carcinoma arising in an odontogenic cyst: a clinicopathologic analysis of 116 reported cases. (2011) J Oral Pathol Med 40: 733-738.

Pubmed | Crossref | Others

2. González-García, R., Sastre-Pérez, J., Nam-Cha, S.H., et al. Primary intraosseous carci- nomas of the jaws arising within an odontogenic cyst, ameloblastoma, and de novo: report of new cases with reconstruction considerations. (2007) Oral Surg Oral Med Oral Pathol Oral Radiol Endod 103(2): e29-33.

Pubmed | Crossref | Others

3. Thomas, G., Pandey, M., Mathew, A., et al. Primary intraosseous carcinoma of the jaw: pooled analysis of world literature and report of two new cases. (2001) Int J Oral Maxillofac Surg 30(4): 349-55.

Pubmed | Crossref | Others

4. Waldron, C.A., Mustoe, T.A. Primary intraosseous carcinoma of the mandible with probable origin in an odontogenic cyst. (1989) Oral Surg Oral Med Oral Pathol 67(6): 716-24.

Pubmed | Crossref | Others

5. Zwetyenga, N., Pinsolle, J., Rivel, J., et al. Primary intraosseous carcinoma of the jaws. (2001) Arch Oto- laryngol Head Neck Surg 127(7): 794-797.

Pubmed | Crossref | Others

Submit your manuscript to Ommega Publishers and we will help you at every step:

- We accept pre-submission inquiries

- Our selector tool helps you to find the most relevant journal

- We provide round the clock customer support

- Convenient online submission

- Thorough peer review

- Inclusion in all major indexing services

- Maximum visibility for your research

Submit your manuscript at

OMMEgA Publishers

https://www.ommegaonline.org/submit-manuscript 